\title{
The effect of sodium chloride and sodium bicarbonate derived anolytes, and anolyte-catholyte combination on biofilms
}

\author{
MS Thantsha and TE Cloete* \\ Department of Microbiology and Plant Pathology, University of Pretoria, Pretoria, South Africa
}

\begin{abstract}
Microbial biofilms are problematic in industrial environments where large areas of submerged surfaces are exposed to relatively high nutrient fluxes, providing niches for the formation of copious surface-associated growth. Biofilms growing in drinking water distribution pipes cause deterioration in the microbiological quality of water contributing to the occurrence of water-borne diseases. Many bacteria are resistant to moderate levels of biocides, with bacteria in biofilms being the most difficult to control. Electrochemical activation (ECA) technology provides an alternative way of controlling these microorganisms. The main objective of this study was to evaluate an electrochemically activated solution, anolyte, as an environmentally safe disinfectant for the control of biofilms. Biofilms were grown using the Pederson device and then exposed to different concentrations of the biocide. Light microscopy and scanning electron microscopy were used to view the effect of treatment on the biofilm structure. Re-growth of the biofilm after treatment with anolyte was detected through epifluorescence microscopy after DAPI staining of the coupons. Neat (undiluted) and mildly dilute anolyte removed the biofilm while the more dilute anolyte did not have any effect on the biofilm. Re-growth of the biofilm occurred after $24 \mathrm{~h}$ of biofilm treatment with anolyte and anolyte-catholyte combination, showed by the increase in colony forming units. Re-growth of planktonic bacteria however, occurred only after $72 \mathrm{~h}$ of treatment.
\end{abstract}

Keywords: Biofilms, electrochemical activation, anolyte, catholyte

\section{Introduction}

Microbial biofilms are problematic in a range of industrial environments where large areas of submerged surfaces are exposed to relatively high nutrient fluxes, providing niches for the formation of copious surface-associated growth (Cloete et al., 1992; Costerton et al., 1994; Videla, 2002). Bacterial colonisation of surfaces in an aqueous environment is a basic strategy for survival in nature as nutrients are more available at the solid-liquid interface (Hoppe, 1984; Lawrence et al., 1987). The resulting aggregates form micro-colonies which develop into biofilms (McCoy et al., 1981). These biofilms promote corrosion of ferrous and other metals by the concerted metabolic activity of a number of biofilm-associated bacterial types (McLeod et al., 1998), a process collectively termed microbially influenced corrosion (MIC). MIC comprises a number of specific mechanisms relating either directly or indirectly to the metabolic activity of a variety of micro-organisms, notably the action of sulphidogenic bacteria (Lee et al., 1995; Dawood and Brözel, 1998). Bacteria colonising the processing equipment in the food industry may be an important source of bacterial contamination, and studies have shown that both spoilage bacteria like Pseudomonas spp. (HallStoodley and Stoodley, 2002) and pathogenic bacteria such as Listeria monocytogens may contaminate products directly from the processing environment (Bagge et al., 2001). As the costs attributable to MIC and biofouling are high, effective control of bacterial numbers in an industrial aqueous environment is essential.

A range of bactericidal substances, commonly termed biocides or micro-biocides are available, all of which are claimed

\footnotetext{
* To whom all correspondence should be addressed.

용 +27124203265 ; fax: +27 124203266 ;

e-mail: eugene.cloete@up.ac.za

Received 16 September 2005; accepted in revised form 30 January 2006.
}

by their producers to kill bacteria occurring in aqueous systems quantitatively (Russel and Chopra, 1990; Chen and Steward, 2000; Videla, 2002). Research has indicated that bacteria growing as biofilms are significantly more resistant to most antimicrobial agents known currently, so that methods for their control pose an ongoing challenge (Cloete et al., 1992; Costerton et al., 1994; Cochran et al., 2000; Russell, 2001; Gilbert et al., 2003; Ludensky, 2003; Vickery and Cossart, 2004). According to Gilbert et al. (2003), biocides are spectacular in their failure to control adherent biofilm communities, and developments to remedy the situation have been limited.

Large doses of biocide or antibiotics which are either detrimental to the environment or above toxic threshold, respectively, are required to eliminate biofilms (Gilbert et al., 2003). Very little information is available on the biodegradability of biocides in natural water systems. This makes biocides hazardous from an environmental point of view. Chlorine is the most widely used oxidising biocide (Norwood and Gilmour, 2000; Meyer, 2003); however, it has its limitations. An environmentally sensible alternative to chlorine and other commonly used biocides is needed.

Electrochemically activated water may provide such an alternative. Water of varying mineralisation is passed through an electrochemical cell, the specific design of which permits harnessing of two distinct and electrically opposite streams of activated water. Aside from its distinctive attributes, the negatively charged antioxidant solution (catholyte) can also be channelled back into the anode chamber, thereby modulating the quality of the positively charged oxidant solution (anolyte) that is produced. Without maintenance of the activated stage these diverse products degrade to the relaxed state of benign water and the anomalous attributes of the activated solutions such as altered conductivity and surface tension similarly revert to pre-activation status. However, the heightened electrical 
activity and altered physico-chemical attributes of solutions differ significantly from the benign state, but yet remain non-toxic to mammalian tissue and the environment. ECA water is less toxic, less volatile, easier to handle, compatible with other water treatment chemicals, effective against biofilms and generates no by-products compared to currently used biocides (Leonov, 1997). The objectives of this study were to evaluate the efficacy of the removal of biofilm by an $\mathrm{NaCl}$ anolyte and anolytecatholyte combination, and by $\mathrm{NaHCO}_{3}$ anolyte.

\section{Materials and methods}

\section{Production of ECA solutions}

ECA solutions were kindly provided by Radical Waters (Pty.) Ltd., Midrand, South Africa. Description of the method of production is outlined by Marais and Brözel (1999).

\section{Biofilm growth and removal}

A modified flow-through Pederson device was used to determine the removal of a Pseudomonas aeruginosa biofilm on stainless steel surfaces and on glass slides. Modifications of the Pederson device were as outlined by Cloete and Jacobs (2001). P. aeruginosa bacterial cells were allowed to attach themselves to glass slides and stainless coupons in nutrient broth (Merck, Pty. Ltd) for two weeks. Samples were removed before and after treatment with $\mathrm{NaCl}$ or $\mathrm{NaHCO}_{3}$ anolyte. Tap water was allowed to flow through the reactor for 20 min before treatment with anolyte. The samples removed after treatment with tap water were used as control. The biofilm was exposed to different concentrations of anolyte for $20 \mathrm{~min}$ for each anolyte concentration. Anolyte dilutions used were 1:10, 1:100 and neat (undiluted) for $\mathrm{NaHCO}_{3}$ anolyte and only 1:10 for $\mathrm{NaCl}$ anolyte. The experiment was performed starting from the less concentrated to the more concentrated anolyte solution. The glass slides were viewed under light microscope while the stainless steel coupons were prepared for scanning electron microscopy.

For biofilm treatment using $\mathrm{NaCl}$ anolyte and an anolytecatholyte combination, bacteria were allowed to adhere to stainless steel coupons for $168 \mathrm{~h}$ in R2A broth (Merck (Pty.) Ltd). The experiment was allowed to proceed for $78 \mathrm{~h}$. Samples were removed before treatment and hourly for $6 \mathrm{~h}$ following treatment. The anolyte-catholyte combination ratio of $2: 1$ and the anolyte were used at a concentration of 1:10. Some of the coupons were used for epifluorescence microscopy while others were prepared for SEM. For both the $\mathrm{NaCl}$ anolyte and anolyte-catholyte combination experiments a control system, using dam water with no added biocide, was included.

\section{Light microscopy}

Microscope slides were removed from the modified Pederson device before and after treatment with biocides. The attached bacteria were observed under oil immersion using a Nikon Optiphot light microscope fitted with a DXM1200 Nikon digital camera.

\section{Scanning electron microscopy}

Coupons $(25 \times 27 \times 1 \mathrm{~mm})$ were removed from the modified Pederson device after 20 min exposure to anolyte solutions. The removed coupons were rinsed with sterile distilled water for $30 \mathrm{~s}$ to remove any unattached cells, then fixed for SEM by the following series of treatments: $2.5 \%$ gluteraldehyde (30 min); $0.15 \mathrm{M}$ phosphate-buffer (3 x $15 \mathrm{~min}) ; 50 \%$ ethanol (1 x $15 \mathrm{~min})$; 70 ethanol (1 x $15 \mathrm{~min}) ; 90 \%$ ethanol (1 x $15 \mathrm{~min})$ and $100 \%$ ethanol $(3 \times 15 \mathrm{~min})$. The coupons were thereafter dried in a critical point dryer, mounted on studs and coated with gold plasma and examined using the JEOL JSM 840 scanning electron microscope.

\section{4, 6-diamidino-z-phenylindole (DAPI) staining}

The coupons were removed from the Pederson device and rinsed with sterile distilled water for $30 \mathrm{~s}$ to remove any unattached cells. The coupons were then stained with DAPI stain for epifluorescence microscopy. Attached bacteria were observed under oil immersion using epifluorescence microscopy. Ten randomly chosen microscope fields were counted under the 800 $\mathrm{x}$ magnification.

\section{Total bacteria counts}

The total number of viable bacteria in the planktonic phase was determined before biocide addition and after $6 \mathrm{~h}$ of treatment with biocide. An $0.1 \mathrm{~m} \ell$ aliquot of the bacterial suspension was plated out on R2A agar plates in duplicates. The plates were incubated for $24 \mathrm{~h}$ at ambient temperature to simulate experimental conditions.

\section{Results and discussion}

\section{Biofilm treatment with sodium bicarbonate anolyte}

Scanning electron microscopy has been used by various researchers to show the presence of biofilms on different surfaces and also to visually estimate biofilm removal from these surfaces by use of biocides (Marais and Brözel, 1999; Cloete and Jacobs, 2001; Gilbert et al., 2003; Pajkos et al., 2004; Vickery and Cossart, 2004). A matured biofilm had formed on both the glass and stainless steel surfaces within four weeks (Figs. $1 \mathrm{~A}$ and $2 \mathrm{~A}$ ) as indicated by light and scanning electron microscopy pictures, respectively. This correlates with a similar study by Cloete and Jacobs (2001) who observed in their study that $P$. aeruginosa readily adhered to the 3CR12 stainless steel coupons and glass in the control system (absence of surfactants). Exposure of the biofilm to a 1:100 dilution of $\mathrm{NaHCO}_{3}$ anolyte did not yield any noticeable removal of biofilm both from the glass slide and the stainless steel coupons (Figs. 1B and 2B). The biofilm structure remained intact as though the biofilm was not subjected to any treatment with a disinfectant. A 1: 10 and a neat (undiluted) solution of anolyte disrupted and removed the biofilm that had formed on the surface of both materials tested after a 20 min exposure (Figs. 1C and 1D; Figs. 2C and 2D). The bigger surface areas on both the glass slides and stainless steel coupons were either clean, or had only a few single bacterial cells. The bacteria found after treatment with 1:10 or neat anolyte were not in clumps as were those found on surfaces treated with 1:100 anolyte dilutions. Thus, removal of biofilm was achieved with the 1:10 dilution or neat anolyte. These results are in agreement with those of Marais and Brözel (1999), who indicated that a mature biofilm present on inner surfaces of dental water unit line tubing was destroyed and removed after 5 weeks of ECA water use. The difference between our study and the latter is that in our case exposure time was much shorter (20 $\mathrm{min}$ ) compared to 5 weeks; nevertheless, ECA solutions were efficient. 
Figure 1

Light microscope pictures of biofilm on glass, (A) control and after treatment with $(B)$ 1: 100, (C) 1:10 and (D) neat sodium bicarbonate derived anolyte. Bar $=1 \mu \mathrm{m}$.
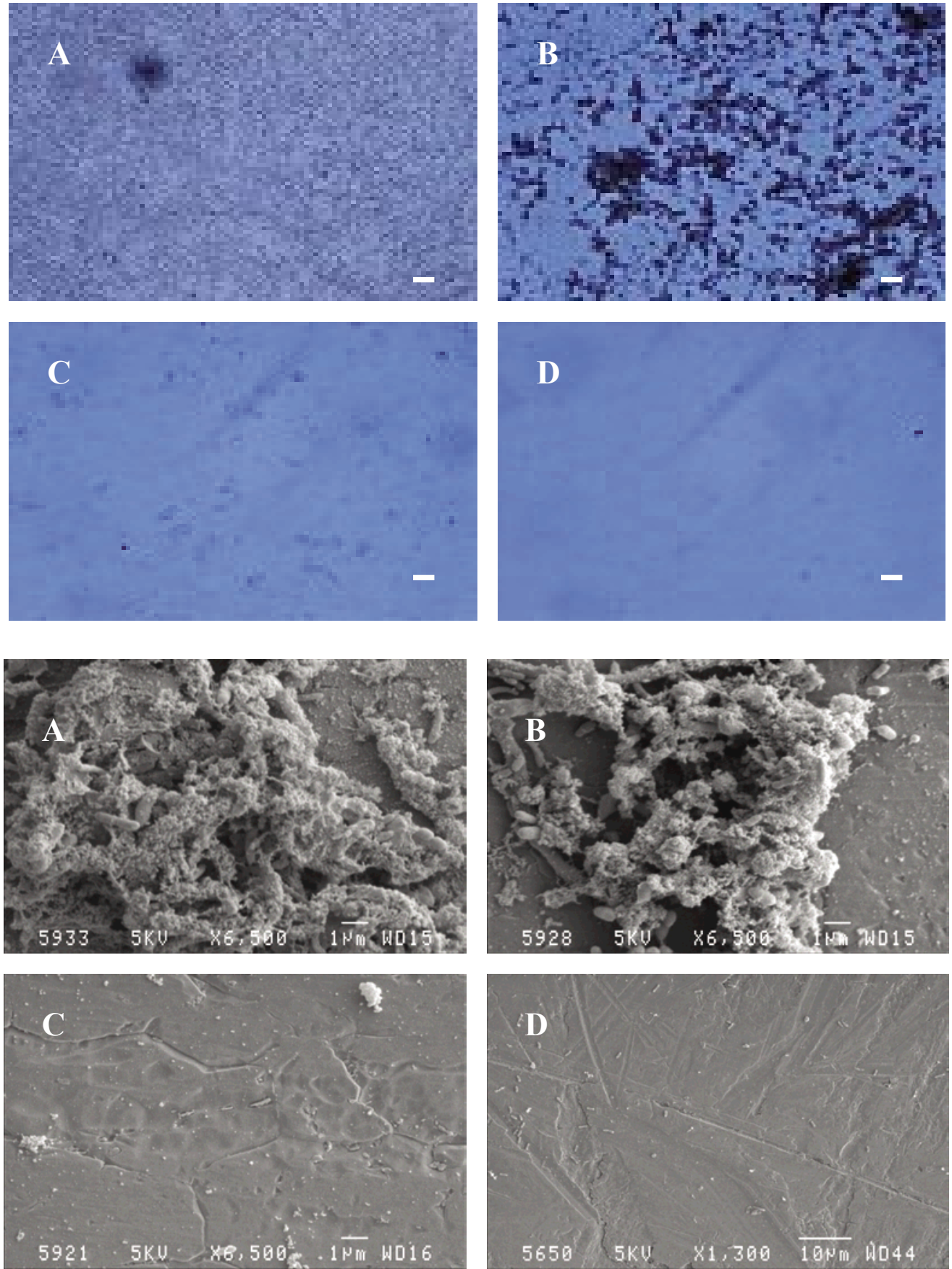

\section{Biofilm treatment with $\mathrm{NaCl}$ anolyte and anolyte- catholyte combination}

The 1:10 anolyte solution effectively removed a mature $P$. aeruginosa biofilm within $6 \mathrm{~h}$ (Figs. 3C, 3D and 3E). The anolyte also reduced the planktonic numbers of bacteria from $2.41 \times 10^{7}$ $\mathrm{cfu} / \mathrm{m} \ell$ to $<10 \mathrm{cfu} / \mathrm{m} \ell$ during the same period (Table 1). The anolyte killed bacteria in the biofilm within $1 \mathrm{~h}$ indicated by fading of the DAPI stain and the decrease in the size of micro-colonies (Fig. 3C). The surface of the coupon after $6 \mathrm{~h}$ of treatment with 1:10 anolyte (Fig. 3E) was nearly as clean as the surface of the coupon with no biofilm growth (Fig. 3A).

Overall, removal of biofilms by both anolytes could be attributed to the presence of free radicals and other antimicrobial agents in these solutions. The free radicals and other anti- microbials present are $\mathrm{ClO}_{2}, \mathrm{ClO}^{-}, \mathrm{H}_{2} \mathrm{O}_{2}, \mathrm{HO}_{2}^{-}, \mathrm{NaOH}, \mathrm{O}_{2}, \mathrm{O}_{3}$, $\mathrm{HClO}, \mathrm{Cl}_{2}, \mathrm{OH}$. Most of these compounds are acidic and have oxidising properties (Leonov, 1997).

The system was operated for a further $72 \mathrm{~h}$ to determine whether biofilm re-growth would occur. Re-growth of the biofilm was observed after $24 \mathrm{~h}$ of treatment (Fig. 3F) shown by the increase in the number and fluorescence intensity of the microcolonies compared to those after $6 \mathrm{~h}$ of treatment (Fig. 3E). Regrowth of planktonic bacteria also occurred as reflected by the increase in cfu to $1.33 \times 10^{6} \mathrm{cfu} / \mathrm{m} \ell$ after $72 \mathrm{~h}$ (Table 1). These results are in agreement with Brözel and Cloete (1992) who indicated that re-growth normally occurs within $48 \mathrm{~h}$ after biocide treatment. Re-growth can be attributed mainly to two factors:

- Firstly, in some instances, a microbial population shift may occur to organisms resistant to the biocide 

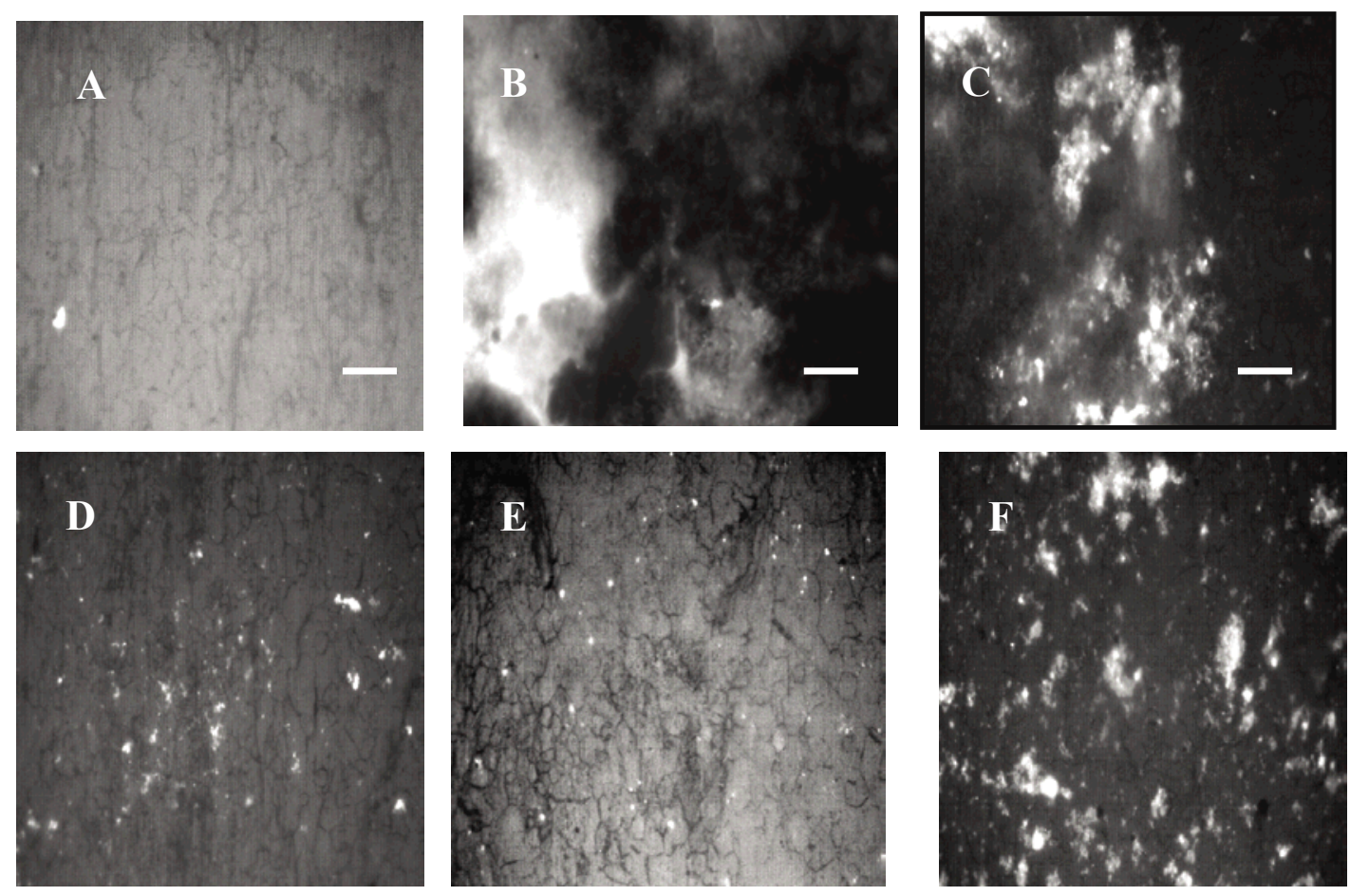

Figure 3

Epifluorescence microscopy pic-

tures of biofilm

after treatment

with $\mathrm{NaCl}$ anolyte,

(A) coupon without

biofilm, (B) biofilm

before treatment,

(C) $1 \mathrm{~h}$ after treat-

ment, (D) $4 \mathrm{~h}$ after

treatment, $(E)$

$6 \mathrm{~h}$ after treatment and $(E) 24 h$ after

treatment.

$B a r=10 \mu m$.
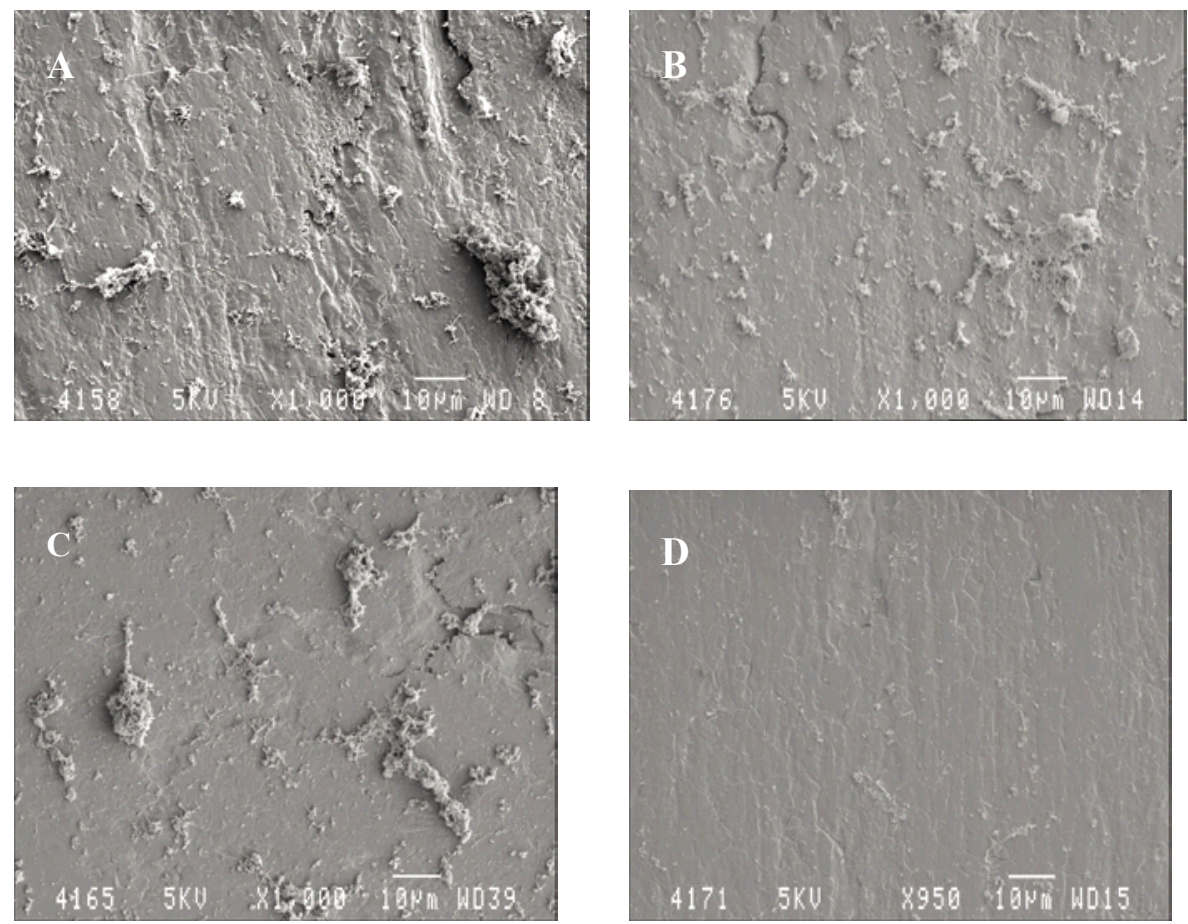

Figure 4

SEM pictures of biofilm, $(A)$ before treatment, (B) $1 \mathrm{~h},(C) 2 \mathrm{~h}$, (D)

$3 h$, (E) $4 h$ and (F) $24 h$ after treatment with $\mathrm{NaCl}$ anolyte/catholyte combination
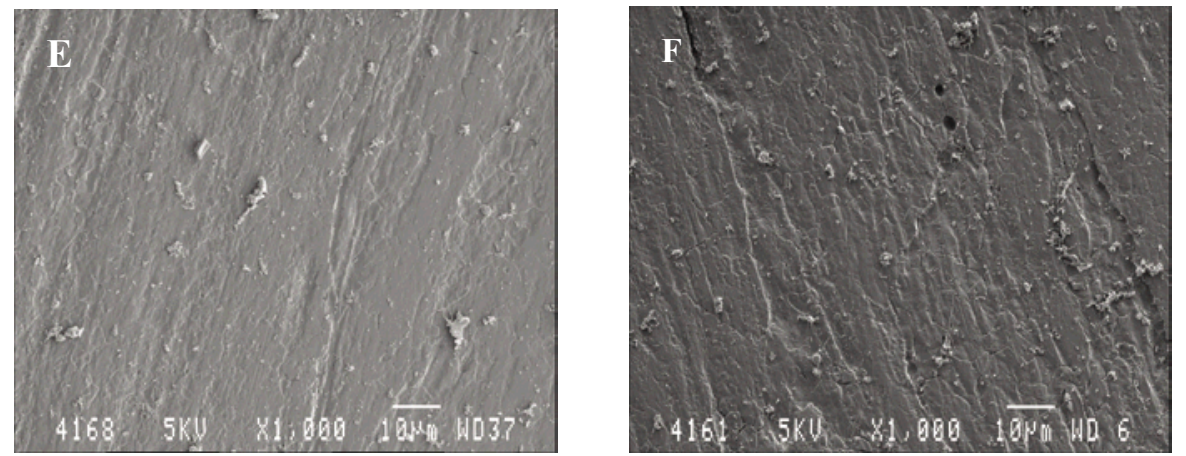
Figure 5

Epifluorescence microscopy pictures of biofilm (A) before treatment, $(B)$ $1 h,(C) 2 h,(D) 3 h,(E)$ $4 h$ and $(E) 24 h$ after treatment with anolyte/ catholyte. Bar $=10 \mu \mathrm{m}$
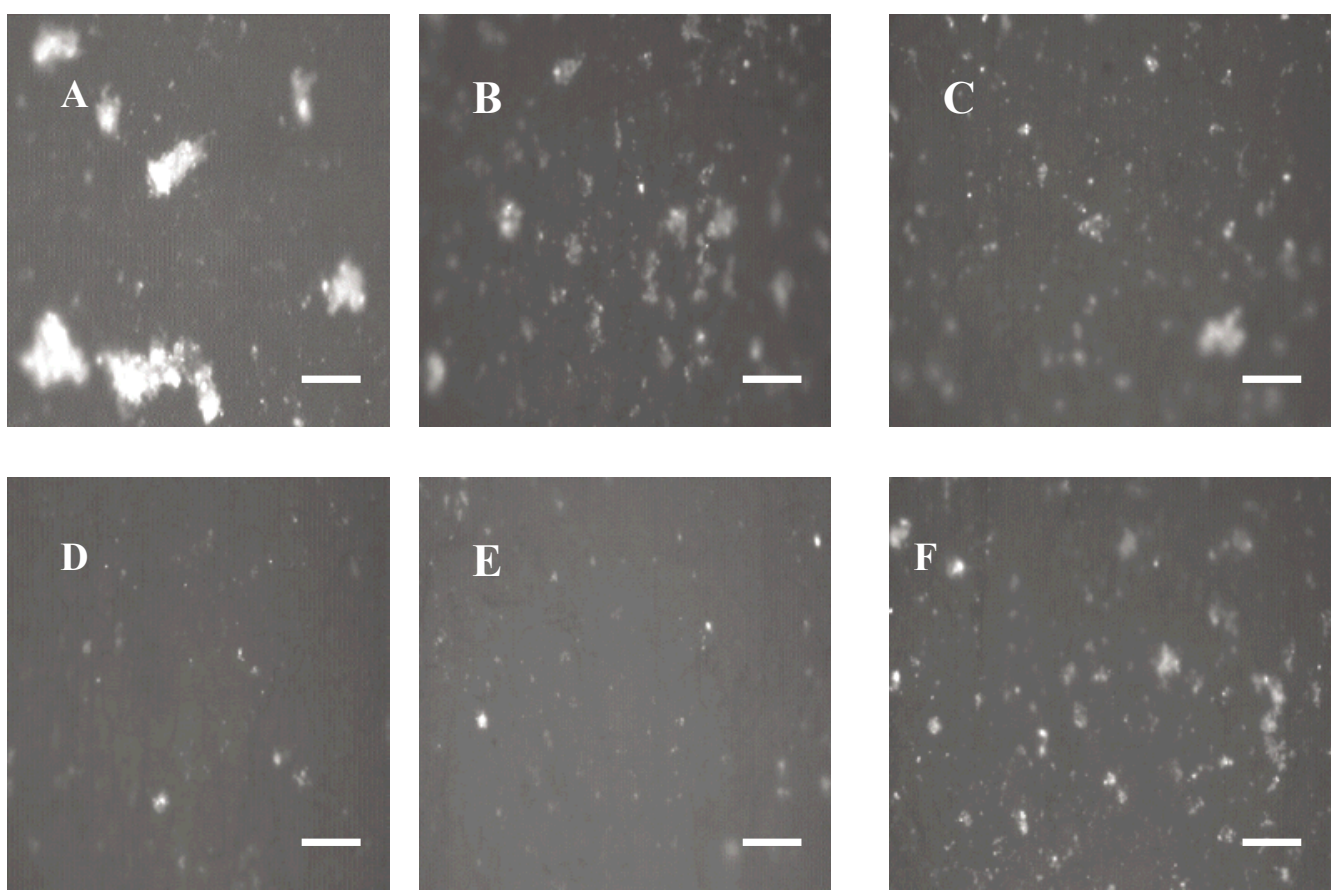

- Secondly, the biocide is "consumed" by organic matter allowing the re-growth of the surviving bacteria.

Gilbert et al. (2003) also mentioned poor penetration of antimicrobials to certain deeper lying communities, exposing these organisms to sublethal levels of antimicrobials over a prolonged time, subjecting them to selection pressures for increased drug resistance and for survival in nutrient depleted environments. Codony et al. (2005) indicated that neutralisation of chlorine in drinking water systems by addition of another chemical, sodium thiosulphate, accelerated the development of microbial communities with reduced susceptibility to disinfection. This could be eliminated through the use of ECA solutions as, when inactivated, they return to a stable state, which is in fact pure water (Leonov, 1997; Marais and Brözel, 1999). As a result the organisms that still remain after treatment will then be in an environment without sublethal concentrations of biocide, or even better without any biocide, and this may reduce or minimise the shift to biocide resistance.

Scanning electron micrographs of the biofilm behaviour before and after treatment with $\mathrm{NaCl}$ anolyte/catholyte combination is indicated in Fig. 4. Surface colonisation could clearly be seen by numerous micro-colonies. These micro-colonies are still visible after $2 \mathrm{~h}$ and $3 \mathrm{~h}$ of treatment.

The micro-colonies seen after $2 \mathrm{~h}$ and $3 \mathrm{~h}$ of treatment are, however, fewer in numbers and smaller in size than those at $0 \mathrm{~h}$ and $1 \mathrm{~h}$ (Figs. 4C and 4D). After $4 \mathrm{~h}$ and $24 \mathrm{~h}$ of treatment very few micro-colonies were observed and the biofilm was no longer noticeable (Figs. 4E and 4F).

The anolyte-catholyte (2:1) solution added at a 1:10 ratio effectively removed the mature $P$. aeruginosa biofilm within 3 to $4 \mathrm{~h}$ (Fig. 5D). There was no removal of biofilm within $1 \mathrm{~h}$ after treatment with anolyte-catholyte combination though there was a noticeable dispersion of the biofilm structure (Fig. 5B). The dispersion and removal of biofilm by anolyte-catholyte combination was due to a combination of oxidising properties of anolyte (Leonov, 1997) and detergent or cleaning effect of catholyte (Marais and Brözel, 1999). Though SEM results showed no difference in the biofilm structure after $4 \mathrm{~h}$ and

\begin{tabular}{|c|c|c|}
\hline \multicolumn{3}{|c|}{$\begin{array}{c}\text { TABLE } 1 \\
\begin{array}{c}\text { Planktonic bacterial numbers after treatment with } \\
\text { tested ECA solutions }\end{array}\end{array}$} \\
\hline \multirow[t]{2}{*}{ Time of sampling } & Anolyte & $\begin{array}{c}\text { Anolyte/catholyte } \\
\text { combination }\end{array}$ \\
\hline & \multicolumn{2}{|c|}{ cfu/me } \\
\hline Before treatment & $2.41 \times 10^{7}$ & $1.14 \times 10^{7}$ \\
\hline $6 \mathrm{~h}$ after treatment & $<10$ & $<10$ \\
\hline $24 \mathrm{~h}$ after treatment & $<10$ & $<10$ \\
\hline $72 \mathrm{~h}$ after treatment & $1.33 \times 10^{6}$ & $1.50 \times 10^{6}$ \\
\hline
\end{tabular}

$24 \mathrm{~h}$ of treatment (Figs. 4E and 4F), DAPI staining indicated re-growth of the biofilm after $24 \mathrm{~h}$ (Fig. 5F). This difference was attributed to the difference in the method of preparation of DAPI and SEM, where the preparation of slides for DAPI is less harsh than for SEM. DAPI staining does not involve a series of dehydration steps required for the SEM preparation procedure, which negatively affect biofilms (Law et al., 2001). When coupons were dehydrated by a series of increasing concentrations of ethanol the re-growing cells might have been washed out as there may not have been enough extracellular polymeric material already produced to firmly attach re-growing cells to the coupon. Re-growth of the planktonic bacteria occurred after $72 \mathrm{~h}$ of treatment with the anolyte-catholyte combination (Table 1).

\section{Conclusions}

- Neat (undiluted) $\mathrm{NaHCO}_{3}$ analyte and 1:10 dilutions of both the $\mathrm{NaCl}$ and $\mathrm{NaHCO}_{3}$ derived anolytes effectively removed the mature $P$. aeruginosa biofilm

- No noticeable biofilm removal was observed when more dilute $(1: 100)$ of both anolytes was used, indicated by the intact biofilm structure

- $\mathrm{NaCl}$ anolyte-catholyte combination effectively removed a mature biofilm, reducing the bacterial numbers from $>10^{7}$ $\mathrm{cfu} / \mathrm{m} \ell$ to less than $10 \mathrm{cfu} / \mathrm{m} \ell$ within $6 \mathrm{~h}$

- Re-growth of the micro-organisms after treatment with ECA solutions was quicker in biofilms than planktonic cells, 
occurring after $24 \mathrm{~h}$ and $72 \mathrm{~h}$, respectively

- ECA solution has the potential to serve as an environmentally safe disinfectant for the control of biofilms.

\section{Acknowledgements}

The authors would like to thank Radical Waters (Pty) Ltd. (Midrand, South Africa) for the provision of ECA solutions, Laboratory for Microscopy and Microanalysis of the University of Pretoria, especially $\mathrm{Mr}$ A Hall, for assistance with the microscopy work, and the University of Pretoria for financial assistance.

\section{References}

BAGGE D, HJELM M, JOHANSEN C and HUBER I (2001) Shewanella putrefaciens adhesion and biofilm formation on food processing surfaces. Appl. Environ. Microbiol. 67 2319-2325.

BRÖZEL VS and CLOETE TE (1992) The effect of bactericide treatment on planktonic bacterial communities in water cooling systems. Water SA 18 87-92.

CHEN X and STEWARD PS (2000) Biofilm removal caused by chemical treatments. Water Res. 34 4229-4233.

CLOETE TE and JACOBS L (2001) Surfactants and the attachment of Pseudomonas aeruginosa to 3CR12 stainless steel and glass. Water SA 27 21-26.

CLOETE TE, BRÖZEL VS and VON HOLY A (1992) Practical aspects of biofouling control in industrial water systems. Int. Biodeter. Biodegrad. 29 299-341.

COCHRAN WL, McFETERS GA and STEWARD PS (2000) Reduced susceptibility of thin Pseudomonas aeruginosa biofilms to hydrogen peroxide and monochloramine. J. Appl. Microbiol. 88 22-30.

CODONY F, MORATÓ J and MAS J (2005) Role of discontinuous chlorination on microbial production by drinking water biofilms. Water Res. 39 1896-1906.

COSTERTON JW, ELLIS B, LAM K, JOHNSON F and KHOURY AE (1994) Mechanism of electrical enhancement of efficacy of antibiotics in killing biofilm bacteria. Antimicrob. Agents Chemother. 38 2803-2809.

DAWOOD Z and BRÖZEL VS (1998) Corrosion enhancing potential of Shewanella putrefaciens isolated from industrial cooling waters. J. Appl. Microbiol. 84 929-936.

GILBERT P, McBAIN AJ, RICKARD AH (2003) Formation of microbial biofilm in hyhienic situations: A problem of control. Int. Biodeter. Biodegrad. 51 245-248.

HALL-STOODLEY L and STOODLEY P (2002) Developmental regulation of microbial biofilms. Curr. Opin. Biotechnol. 13 228-233.
HOPPE HG (1984) Attachment of bacteria: Advantage and $\backslash$ or disadvantage for survival in the aquatic system. In: Marshall KC (ed.) Microbial Adhesion and Aggregation. Berlin, Springer Verlag. pp 283-301.

LAW SP, MELIVIN MMAL and LAMB AJ (2001) Visualization of the establishment of a heterotrophic biofilm within the Schmutzdecke of a slow sand filter using scanning electron microscopy. Biofilm J. 6 Paper 1(BF01001).

LAWRENCE JR, DELAQUIS PJ, KORBER DR and CALDWELL DE (1987) Behaviour of Pseudomonas fluorescens within the hydrodynamic boundary layers of surface microenvironments. Microb. Ecol. 14 1-14.

LEE W, LEWANDOWSKI ZL, NIELSEN PH and HAMILTON WA (1995) Role of sulphate reducing bacteria in corrosion of mild steel: A review. Biofouling 8 165-194.

LEONOV BI (1997) Electrochemical activation of water and aqueous solutions: Past, present and future. Proc. 1st Int. Symp. on Electrochem. Activation, Moscow. 11-27.

LUDENSKY M (2003) Control and monitoring of biofilms in industrial applications. Int. Biodeter. Biodegrad. 51 255-263.

MARAIS JT and BRÖZEL VS (1999) Electro-chemically activated water in dental unit water lines. Br. Dent. J. 187 154-158.

McLEOD ES, DAWOOD Z, MACDONALD R, OOSTHUIZEN M, GRAF J, STEYN PL and BRÖZEL VS (1998) Isolation and identification of sulphite- and iron reducing, hydrogenase positive facultative anaerobes from cooling water systems. Syst. Appl. Microbiol. 21 297-305.

McCOY WF, BRYERS JD, ROBBINS J and COSTERTON JW (1981) Observations of fouling biofilm formation. Can. J. Microbiol. 27 910-917.

NORWOOD DE and GILMOUR A (2000) The growth and resistance to sodium hypochlorite of Listeria monocytogens in a steady-state multispecies biofilm. J. Appl. Microbiol. 88 512-520.

MEYER B (2003) Approaches to prevention, removal and killing of biofilms. Int. Biodeter. Biodegrad. 51 249-253.

PAJKOS A, VICKERY K and COSSART Y (2004) Is biofilm accumulation on endoscope tubing a contributor to the failure of cleaning and decontamination? J. Hosp. Infect. 58 224-229.

RUSSELL AD (2001). Mechanisms of bacterial insusceptibility to biocides. Am. J. Infect. Control 29 259-261.

RUSSEL AD and CHOPRA I (1990) Understanding Antibacterial Action and Resistance. Ellis Horwood, New York.

VICKERY K and COSSART Y (2004) Removal of biofilm from endoscopes: Evaluation of detergent efficiency. Am. J. Infect. Control 32 170-176.

VIDELA HA (2002) Prevention and control of biocorrosion. Int. Biodeter. Biodegrad. 49 259-270. 